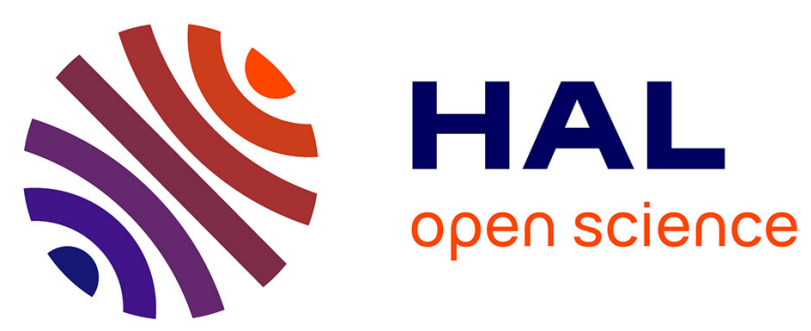

\title{
Functional imaging of pain
}

\author{
R. Peyron, C. Fauchon
}

\section{To cite this version:}

R. Peyron, C. Fauchon. Functional imaging of pain. Revue Neurologique, 2019, 175, pp.38 - 45. 10.1016/j.neurol.2018.08.006 . hal-03485633

\section{HAL Id: hal-03485633 \\ https://hal.science/hal-03485633}

Submitted on 20 Dec 2021

HAL is a multi-disciplinary open access archive for the deposit and dissemination of scientific research documents, whether they are published or not. The documents may come from teaching and research institutions in France or abroad, or from public or private research centers.
L'archive ouverte pluridisciplinaire HAL, est destinée au dépôt et à la diffusion de documents scientifiques de niveau recherche, publiés ou non, émanant des établissements d'enseignement et de recherche français ou étrangers, des laboratoires publics ou privés.

\section{다)(1) $(5$}

Distributed under a Creative Commons Attribution - NonCommerciall 4.0 International 


\title{
In-situ study of cationic oxidation states in $\mathrm{Pr}_{2} \mathrm{NiO}_{4+\delta}$ using X-ray Absorption Near-Edge Spectroscopy
}

T. Ogier ${ }^{1}$, C. Prestipino², S.Figueroa ${ }^{3}$, F. Mauvy¹, J. Mougin ${ }^{4}$, J.C. Grenier ${ }^{1}$, A. Demourgues ${ }^{1}$ and J.M. Bassat ${ }^{1, *}$

${ }^{1}$ CNRS, Université de Bordeaux, ICMCB, 87 avenue du Dr. A. Schweitzer, 33608 Pessac, France ${ }^{2}$ Univ. Rennes, CNRS, ISCR (Institut des Sciences Chimiques de Rennes) UMR 6226 35042, Rennes, France

${ }^{3}$ European Synchrotron Radiation Facility, 6 rue Jules Horowitz, BP220, 38043, Grenoble Cedex, France ${ }^{4}$ CEA-Grenoble, LITEN/DTBH/LTH 17 rue des Martyrs, 38054 Grenoble Cedex 9, France

* corresponding author: jean-marc.bassat@icmcb.cnrs.fr

\begin{abstract}
The mean oxidation state of cationic elements in $\mathrm{Pr}_{2} \mathrm{NiO}_{4+\delta}$ was studied using XANES measurements versus temperature in air. Unexpectedly, praseodymium is solely found as $\mathrm{Pr}^{3+}$ while $\mathrm{Pr}^{4+}$ was also foreseeable. $\mathrm{Pr}^{3+}$ cation is well accommodated in the large rare-earth site with the nine-fold coordination in this $\mathrm{K}_{2} \mathrm{NiF}_{4}-\mathrm{T}$-type structure; conversely, the small size of the $\mathrm{Pr}^{4+}$ cation seems not compatible with this site. Moreover, XANES measurements show a progressive decrease of the mean oxidation state of nickel ions when the temperature increases. It is directly correlated to the decrease of the oxygen over-stoichiometry of the material evidenced by TGA measurements.
\end{abstract}

Keywords: praseodymium nickelate, $\mathrm{K}_{2} \mathrm{NiF}_{4}-\mathrm{T}$-type structure, XANES, Ni K-edge, $\mathrm{Pr}$ LIII-edge, oxidation states, SOFC, SOEC 


\section{Introduction}

Early oxygen electrode materials for high temperature devices such as SOFC (Solid Oxide Fuel Cell) and/or SOEC (Solid Oxide Electrolysis Cell) were composites including LSM (strontium lanthanum manganite with high electronic conductivity) and a pure oxide conductor such as yttria-doped zirconia (YSZ) [1]. A more recent way is to use materials with MIEC (Mixed Ionic and Electronic Conducting) properties. In this frame, i) oxygen deficient $(\mathrm{La}, \mathrm{Sr})(\mathrm{Co}, \mathrm{Fe}) \mathrm{O}_{3-\delta}$ perovskites have been mainly developed among the last two decades, being the compositions $\mathrm{La}_{0.6} \mathrm{Sr}_{0.4} \mathrm{Fe}_{0.8} \mathrm{CO}_{0.2} \mathrm{O}_{3-\delta}$ and $\mathrm{La}_{0.6} \mathrm{Sr}_{0.4} \mathrm{CoO}_{3-\delta}$ considered as reference electrode materials [2]; ii) oxygen over-stoichiometric nickelates $\mathrm{Ln}_{2} \mathrm{NiO}_{4+\delta}(\mathrm{Ln}=\mathrm{La}, \mathrm{Pr})$ are also very efficient oxygen electrodes thanks to high values of both surface exchange and oxygen diffusion coefficients, especially at intermediate temperatures $\left(500-600{ }^{\circ} \mathrm{C}\right)$ [3]. Among them, $\mathrm{La}_{2} \mathrm{NiO}_{4+\delta}$ is the most investigated material. However the best electrochemical results have been obtained when using $\mathrm{Pr}_{2} \mathrm{NiO}_{4+\delta}$ [4]. For instance, among the different nickelates, the lowest polarization resistance values are measured in the intermediate temperature range $\left(\mathrm{T} \leq 800^{\circ} \mathrm{C}\right)$ under zero $d c$ conditions, in air when porous $\mathrm{Pr}_{2} \mathrm{NiO}_{4+\delta}$ is screen-printed on a thin $(2-4 \mu \mathrm{m})$ and almost dense doped (yttrium or gadolinium) ceria layer $[4,5]$, while dense 8 mol\% yttriadoped zirconia (8YSZ) is the main electrolyte. Even, better results are obtained when $\mathrm{Pr}_{2} \mathrm{NiO}_{4+\delta}$ is infiltrated in a porous $\mathrm{Gd}$-doped ceria backbone [6], then leading to a composite oxygen electrode. Moreover, high current densities are recorded on single cells with $\mathrm{Pr}_{2} \mathrm{NiO}_{4+\delta}$ as oxygen electrode, either as cathode [4] or anode [7] in SOFC or SOEC cells.

The structure of $\mathrm{Ln}_{2} \mathrm{NiO}_{4+\delta}$ consists of alternate $\mathrm{NiO}_{2}$ square-plan layers and $\mathrm{Ln}_{2} \mathrm{O}_{2}$ rock salt-type layers, leading to the first member $(n=1)$ of the so-called Ruddlesden-Popper series with $\mathrm{Ln}_{n+1} \mathrm{Ni}_{n} \mathrm{O}_{3 n+1}$ formulation [8]. $\mathrm{Ln}_{2} \mathrm{NiO}_{4+\delta}$ phases tolerate a wide range of oxygen over-stoichiometry $\delta$, the additional oxygen being located in the rock-salt like layer in a [ $\left.\mathrm{Ln}_{4}\right]$ tetrahedron [9]. The $\delta$ value mainly depends on the rare-earth size (the smaller the ionic radius, the higher the $\delta$ value); for instance, because praseodymium and neodymium have smaller cationic radii (1.126 and $1.109 \AA$, respectively) than that of lanthanum (1.16 $\AA$ ) [10], their corresponding $\delta$ value is higher (around $\delta=0.22-0.23$ at room temperature) instead of $\delta=0.14$ for La. The fast diffusion of oxide ions results from an efficient so-called interstitialcy mechanism involving both apical and additional oxygen-types [11]. However, a still open question is that, despite very similar oxygen overstoichiometry values, $\mathrm{Nd}_{2} \mathrm{NiO}_{4+\delta}$ and $\mathrm{Pr}_{2} \mathrm{NiO}_{4+\delta}$ have somewhat different oxygen diffusion coefficients as well as different activation energies [12]. In particular, in the lower operating temperature range $\left(450<\mathrm{T}^{\circ} \mathrm{C}<\right.$ $600), \mathrm{Pr}_{2} \mathrm{NiO}_{4+\delta}$ exhibits the highest values of oxygen diffusion.

To ensure long-term performances, a better understanding of the temperature governed redox behaviour (oxygen reduction and incorporation) of this class of compounds is of utmost importance. They are able to exchange oxygen reversibly with air atmosphere, even at low temperature [13]. While the redox process mainly involves the transition metal cation species (here $\mathrm{Ni}^{3+} / \mathrm{Ni}^{2+}$ ), in the peculiar case of $\mathrm{Pr}_{2} \mathrm{NiO}_{4+\delta}$ one may wonder to which extent the praseodymium could also be concerned, because both $\mathrm{Pr}^{3+}$ and $\mathrm{Pr}^{4+}$ cations can formally be formed in this material. Such a phenomenon has been evidenced for example in oxygen understoichiometric oxides such as $\operatorname{Pr}_{6} \mathrm{O}_{11}$ and $\operatorname{Pr}_{7} \mathrm{O}_{12}[14,15]$, as well as in the $\operatorname{Pr}_{1-x} \mathrm{Zr}_{x} \mathrm{O}_{2-y}$ solid solution, in which the $\mathrm{Pr}^{4+} / \mathrm{Pr}^{3+}$ ratio is directly controlled by the zirconium amount (higher the zirconium content, lower the praseodymium oxidation state) [16]. The occurrence of $\mathrm{Pr}^{3+} / \mathrm{Pr}^{4+}$ mixed valence in $\mathrm{Pr}_{2} \mathrm{NiO}_{4+\delta}$ has to be carefully checked in order to understand why the electrochemical performances of $\mathrm{Pr}_{2} \mathrm{NiO}_{4+\delta}$ are better than those of $\mathrm{Nd}_{2} \mathrm{NiO}_{4+\delta}[4,12]$. Indeed, it is initially expected that the over-stoichiometry governs the high temperature MIEC properties, the oxygen diffusion properties being directly correlated with the $\mathrm{Ni}^{2+} / \mathrm{Ni}^{3+}$ ratio adjustment vs. temperature and $\mathrm{pO}_{2}$. The $\mathrm{Pr}^{3+} / \mathrm{Pr}^{4+}$ ratio should play the same role. One should note that the same situation cannot occur in $\mathrm{Nd}_{2} \mathrm{NiO}_{4+\delta}$, the neodymium cation having only the 3+ oxidation state.

The superior ionic conducting properties of $\mathrm{Pr}_{2} \mathrm{NiO}_{4+\delta}$ are illustrated in Fig.1, which gathers the thermal variation of the oxygen $D^{*}$ (tracer) diffusion coefficients for the main materials used as oxygen electrodes. 


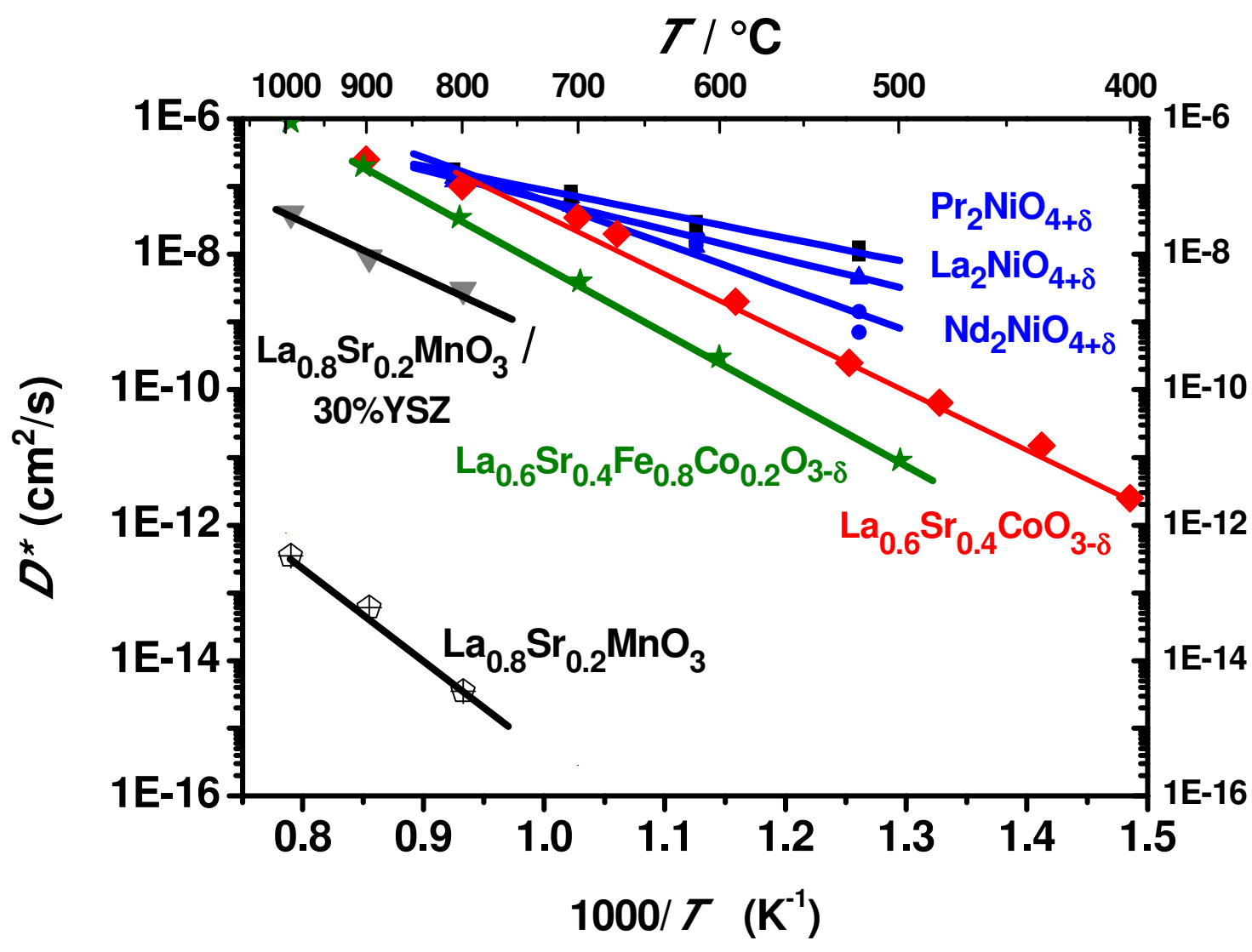

Figure 1 - Thermal evolution of the oxygen diffusion coefficients for different oxygen electrode materials:

$\mathrm{La}_{0.8} \mathrm{Sr}_{0.2} \mathrm{MnO}_{3}$ [17], $\mathrm{La}_{0.8} \mathrm{Sr}_{0.2} \mathrm{MnO}_{3} / 30 \%-\mathrm{YSZ} /$ [17], $\mathrm{La}_{0.6} \mathrm{Sr}_{0.4} \mathrm{Co}_{0.2} \mathrm{Fe}_{0.8} \mathrm{O}_{3-\delta}$ [18], $\mathrm{La}_{0.6} \mathrm{Sr}_{0.4} \mathrm{CoO}_{3-\delta}$ [19], $\mathrm{La}_{2} \mathrm{NiO}_{4+\delta}, \mathrm{Pr}_{2} \mathrm{NiO}_{4+\delta}$ and $\mathrm{Nd}_{2} \mathrm{NiO}_{4+\delta}[20]$.

The oxygen (tracer) diffusion is very low for LSM whatever the temperature $\left(D^{*} \sim 10^{-14} \mathrm{~cm}^{2} \cdot \mathrm{s}^{-1}\right.$ at $\left.800^{\circ} \mathrm{C},[17]\right)$. It is improved by about five orders of magnitude when a composite with YSZ is prepared (YSZ-30\% LSM) [17]. However these values are somewhat lower than those measured for $\mathrm{La}_{0.6} \mathrm{Sr}_{0.4} \mathrm{Co}_{0.2} \mathrm{Fe}_{0.8} \mathrm{O}_{3-\delta}\left(\mathrm{D}^{*} \sim 3.10^{-8}\right.$ $\mathrm{cm}^{2} . \mathrm{s}^{-1}$ at $\left.800^{\circ} \mathrm{C}[18]\right)$ and about one order of magnitude lower than those of $\mathrm{La}_{0.6} \mathrm{Sr}_{0.4} \mathrm{CoO}_{3-\delta}\left(\mathrm{D}^{*} \sim 5.10^{-7}\right.$ $\mathrm{cm}^{2} \cdot \mathrm{s}^{-1}$ at $\left.800^{\circ} \mathrm{C}[19]\right)$.

The oxygen diffusion coefficients of both $\mathrm{Nd}_{2} \mathrm{NiO}_{4+\delta}$ and $\mathrm{Pr}_{2} \mathrm{NiO}_{4+\delta}$ are slightly higher at $800^{\circ} \mathrm{C}\left(\mathrm{D}^{*} \sim 1.10^{-6}\right.$ $\mathrm{cm}^{2} . \mathrm{s}^{-1}$ [20]), the values for $\mathrm{La}_{2} \mathrm{NiO}_{4+\delta}$ being between these two. A major improvement is also evidenced in the lowest temperature range, and especially regarding $\mathrm{Pr}_{2} \mathrm{NiO}_{4+\delta}: \mathrm{D}^{*} \sim 1.10^{-8} \mathrm{~cm}^{2} . \mathrm{s}^{-1}$ at $500^{\circ} \mathrm{C}$ [20] against $D^{*} \sim 1.10^{-10} \mathrm{~cm}^{2} . \mathrm{s}^{-1}$ for $\mathrm{La}_{0.6} \mathrm{Sr}_{0.4} \mathrm{CoO}_{3-\delta}[19]$ and $\mathrm{D}^{*} \sim 1.10^{-10} \mathrm{~cm}^{2} . \mathrm{s}^{-1}$ for $\mathrm{La}_{0.6} \mathrm{Sr}_{0.4} \mathrm{Co}_{0.2} \mathrm{Fe}_{0.8} \mathrm{O}_{3-\delta}[18]$ at the same temperature.

Therefore, because i) as explained above the oxygen over-stoichiometry amount is not the key parameter explaining the superior MIEC properties of $\mathrm{Pr}_{2} \mathrm{NiO}_{4+\delta}$ and, ii) any data are till now available in the literature (to our knowledge), it is of importance to learn more about the possible formation of $\operatorname{Pr}^{4+}$ cation in $\operatorname{Pr}_{2} \mathrm{NiO}_{4+\delta}$. For this purpose, in-situ X-ray absorption spectroscopy (XAS) has been used combined with TGA measurements in order to evaluate the oxygen release process occurring for $\mathrm{Pr}_{2} \mathrm{NiO}_{4+\delta}$ at increasing temperature (from room temperature up to $700^{\circ} \mathrm{C}$ ), in air. 


\section{Experimental}

Powder of $\mathrm{Pr}_{2} \mathrm{NiO}_{4+\delta}$ was prepared from the nitrate-citrate route, using citric acid as a chelating agent, as previously described [21]. The final annealing was performed in air at $1100^{\circ} \mathrm{C}$, then at $1150^{\circ} \mathrm{C}$ for 3 hours at each temperature, with the aim to obtain a well crystallized single phase, as checked by powder X-ray diffraction (PANalytical X'Pert Pro diffractometer, CuKa). $\mathrm{Pr}_{2} \mathrm{NiO}_{4+\delta}$ crystallizes in the orthorhombic $\mathrm{K}_{2} \mathrm{NiF}_{4^{-}}$ type structure with the Bmab space group.

Before performing the X-ray absorption studies, the thermal evolution of the oxygen over-stoichiometry of the material was determined under flowing dry air by thermo-gravimetric analysis (TGA). For this purpose, the powder was heated under air up to $1000^{\circ} \mathrm{C}$ and cooled down to room temperature with a $2{ }^{\circ} \mathrm{C} \cdot \mathrm{min}^{-1} \mathrm{rate}_{\text {. }}$ After several reversible oxygen exchange cycles, the oxygen composition of the sample cooled down to room temperature was considered stable and the $\delta$ value at room temperature was determined using a complete reduction of the sample under $\mathrm{Ar} / 5 \% \mathrm{H}_{2}$ flow [22].

Cationic valences in $\mathrm{Pr}_{2} \mathrm{NiO}_{4+\delta}$ were investigated using XANES (X-ray Absorption Near-Edge Spectroscopy) at the nickel $\mathrm{K}$ and praseodymium $\mathrm{L}_{\text {III }}$ absorption edges (8333 and $5944 \mathrm{eV}$, respectively). Spectra were recorded using synchrotron radiation on the BM23 beam line at the European Synchrotron Radiation Facility (ESRF), France [23]. Because the two considered absorption edges are quite closed the data were collected using the same beam line settings. The measurements were carried out in the transmission mode, using a $\mathrm{Si}$ (111) fixed exit double crystal monochromator. Harmonic rejection was obtained by the use of a silicon coated mirror after the monochromator. Additional data were collected at room temperature using appropriate standard materials (i.e. with single and well known cationic oxidation states) such as $\mathrm{NiO}, \mathrm{LaNiO}_{3}, \mathrm{PrF}_{3}$ and $\operatorname{Pr}_{0.5} \mathrm{Ce}_{0.5} \mathrm{O}_{2}$ to provide references for the $\mathrm{Ni}^{2+}, \mathrm{Ni}^{3+}, \mathrm{Pr}^{3+}$ and $\mathrm{Pr}^{4+}$ absorption edges, respectively. $\operatorname{PrF}_{3}$ was kept in a glove box, before transportation in an airtight container. The XANES spectra of Pr-based oxides exhibit one main line assigned to $4 \mathrm{f}^{2}\left(\mathrm{Pr}^{3+}\right)$ and, in addition in the case of $\mathrm{Pr}^{4+}$ compounds, a higher energy satellite due to the $4 \mathrm{f}^{1}$ final state configuration. However, in mixed valence Pr-based compounds $\left(\mathrm{Pr}^{3}+\mathrm{Pr}^{4+}\right.$ oxides) one should notice that the replicate splitting, due to the two possible configurations, is about 8-9 eV when the passive electrons are included. It is equal to the energy by which the $4 \mathrm{f}$ level is lowered by the core hole [24]: the $4 \mathrm{f}$ level at the Fermi level is degenerated with $5 \mathrm{~d} 6 \mathrm{~s}$ delocalized band and the ground state fluctuates between $4 f^{2}(5 d 6 s) 3 \Leftrightarrow 4 f^{1}(5 d 6 s) 4$ configurations of the valence electrons. To make sure a reliable comparison with the recorded data, the standards for $\mathrm{Ni}^{2+}(\mathrm{NiO})$ and $\mathrm{Ni}^{3+}\left(\mathrm{LaNiO}_{3}\right)$ were chosen to have nickel in 6-fold coordinated sites. Pure oxygen stoichiometric $\operatorname{Pr}_{0.5} \mathrm{Ce}_{0.5} \mathrm{O}_{2}$, where praseodymium has only the $\mathrm{Pr}^{4+}$ oxidation state, was prepared as reference for $\mathrm{Pr}^{4+}$ edge. According to a previous study [16], the co-precipitation route was used and the sample was heated up to $1200^{\circ} \mathrm{C}$ under air in order to adjust the oxygen stoichiometry.

Samples for XANES analyses were prepared by grinding the powder to homogeneity in a matrix of boron nitride $\mathrm{BN}$ and pressing into disks of $13 \mathrm{~mm}$ diameter to make sure that the optimal absorption spectra were measured.

In order to investigate the redox processes in $\mathrm{Pr}_{2} \mathrm{NiO}_{4+\delta}$, XANES data were collected at temperatures ranging from $25^{\circ} \mathrm{C}$ to $700^{\circ} \mathrm{C}$. This was achieved using an internal heating element with temperature measurement managed by an external control unit. In-situ data were collected isothermally on heating cycle using a $10^{\circ} \mathrm{C} / \mathrm{min}$ rate, under controlled atmosphere with 20 vol\% oxygen and 80 vol\% helium gas flowing.

Absorbance data were background subtracted and normalized. The absence of energy shift during the measurement was confirmed through the use of Ni reference, collected simultaneously to the sample of interest. The nickel K-edge position was found by taking the position of the zero-crossing in the second derivative of the corresponding XANES spectrum. The intrinsic error on the determination of the zero-crossing point has been defined as $0.025 \mathrm{eV}$ (1/4 of the sampling step), leading to an error on the nickel oxidation state of about 0.010. Another way to determine the nickel oxidation state in $\mathrm{Pr}_{2} \mathrm{NiO}_{4+\delta}$ was the following one: 
the XANES spectrum recorded for the standard compound for $\mathrm{Ni}^{2+}$ and $\mathrm{Ni}^{3+}$ were integrated between the isosbestic points at $8337.2 \mathrm{eV}$ and $8349.8 \mathrm{eV}$. A linear relationship was considered between nickel oxidation state and integrated surface area for $\mathrm{Ni}^{2+}$ and $\mathrm{Ni}^{3+}$ standards. The $\mathrm{Pr}_{2} \mathrm{NiO}_{4+\delta}$ data were similarly integrated over the same energy range. The nickel oxidation state in $\mathrm{Pr}_{2} \mathrm{NiO}_{4+\delta}$ was determined using the calibration curve based on standard integrations. Using such a method and energy limits differing of $1 \mathrm{eV}$, leads to an error on the nickel oxidation state of about 0.015 was estimated.

\section{Results and discussion}

\section{Determination of the praseodymium oxidation state in $\mathrm{Pr}_{2} \mathrm{NiO}_{4+\delta}$}

The XANES data collected under air for $\mathrm{Pr}_{2} \mathrm{NiO}_{4+\delta}$ in the temperature range $25^{\circ} \mathrm{C}<\mathrm{T}<700^{\circ} \mathrm{C}$ are plotted in Figure 2. The differences between the various curves cannot be easily distinguished because they are quite perfectly superimposed. The XANES spectra for the praseodymium standards recorded at room temperature in air are also shown for comparison.

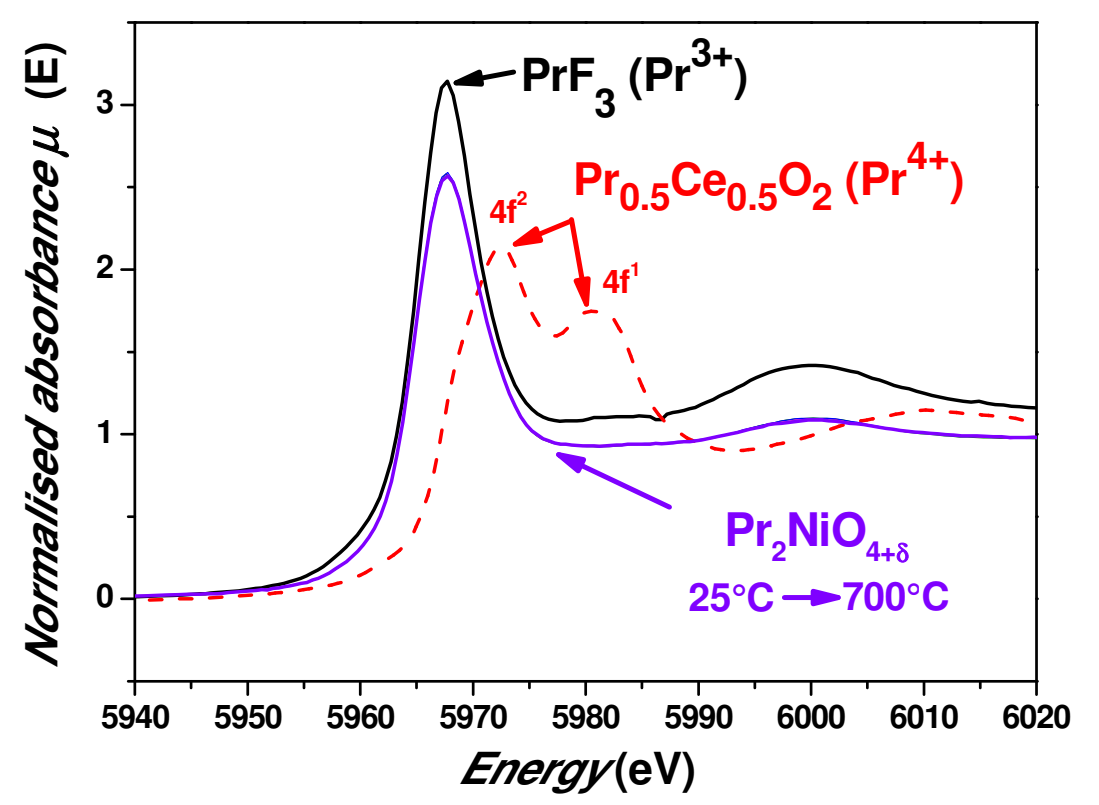

Fiqure 2. XANES data collected at the LIII-edge of praseodymium, for $\operatorname{PrF}_{3}$ and $\operatorname{Pr}_{0.5} \mathrm{Ce}_{0.5} \mathrm{O}_{2}$ at room temperature in air. For $\mathrm{Pr}_{2} \mathrm{NiO}_{4+\delta}$, the spectra were collected in the temperature range $25-700^{\circ} \mathrm{C}$ in $20 \% \mathrm{O}_{2}$ diluted in helium.

The Pr-LIII XANES spectrum recorded for $\mathrm{PrF}_{3}$ has a unique absorption peak characteristic of $\mathrm{Pr}^{3+}$ cations. On the contrary, the corresponding spectrum related to $\mathrm{Pr}_{0.5} \mathrm{Ce}_{0.5} \mathrm{O}_{2}$ perfectly evidences the variation of the valence states for this cation as detailed in the experimental section, with the two main peaks (located at 5970 and $5981 \mathrm{eV}$ ) assigned to the $4 \mathrm{f}^{2}$ and $4 \mathrm{f}^{1}$ electronic configurations, respectively [25-27]. Spectra of $\mathrm{Pr}_{2} \mathrm{NiO}_{4+\delta}$ collected in the temperature range $25-700{ }^{\circ} \mathrm{C}$ are superimposed whatever the temperature, indicating that the oxidation state of praseodymium does not change as a function of temperature. Moreover, the spectrum profile is similar to that of $\mathrm{Pr}^{3+}$ in $\mathrm{PrF}_{3}$, the location as well as the mid-height width being the same. Then, it can be concluded that $\mathrm{Pr}_{2} \mathrm{NiO}_{4+\delta}$ only contains $\mathrm{Pr}^{3+}$, between 25 and $700^{\circ} \mathrm{C}$, under air. This result is in good agreement with previous hypotheses given in the paper by Zhang et al. regarding $\mathrm{Pr}_{4} \mathrm{Ni}_{3} \mathrm{O}_{10 \pm \delta}$ [28]. These authors discussed the variation of the cell parameters in the $n=3$ term of the RP series for $L n=L a$, $\mathrm{Nd}$ and $\mathrm{Pr}$. Assuming a significant amount of $\mathrm{Pr}^{4+}$ to be present in the $\mathrm{Pr}_{4} \mathrm{Ni}_{3} \mathrm{O}_{10 \pm \delta}$ phase, both the c parameter and the tolerance factor would be considerably reduced. But the $c$ parameter of $\mathrm{Pr}_{4} \mathrm{Ni}_{3} \mathrm{O}_{10 \pm \delta}$ lying on the same 
curve as the c parameters of $\mathrm{La}_{4} \mathrm{Ni}_{3} \mathrm{O}_{10 \pm \delta}$ and $\mathrm{Nd}_{4} \mathrm{Ni}_{3} \mathrm{O}_{10 \pm \delta}$, it confirms the presence of only $\mathrm{Pr}^{3+}$. Moreover, considering competitive bonds around oxygen atoms, covalent $\mathrm{Ni}^{2+}-\mathrm{O}^{2-}$ bonds contribute to stabilize the ionic $\mathrm{Pr}^{3+}-\mathrm{O}^{2-}$ bond (compared to the $\mathrm{Pr}^{4+}-\mathrm{O}^{2-}$ one). Therefore, it is believed that in $\mathrm{Pr}_{4} \mathrm{Ni}_{3} \mathrm{O}_{10 \pm \delta}$ as well, praseodymium is primarily in the +3 oxidation state.

According to the work of Tan et al. [26] performed on substituted rare-earth cuprates $\mathrm{Ln}_{2} \mathrm{CuO}_{4}(\mathrm{Ln}=\mathrm{La}, \mathrm{Pr}$, $\mathrm{Nd}$ ) having the same structural type than the nickelates here studied, the praseodymium valence is correlated to the cristallographic structure of the materials. Indeed, while only $\mathrm{Pr}^{3+}$ was observed in T-type (such as PrSrCuO $\left.{ }_{4-\delta}\right)$ and T'-type structures $\left(\mathrm{Pr}_{2} \mathrm{CuO}_{4-\delta}\right)$ using XAS measurements, a small amount of $\mathrm{Pr}^{4+}$ was evidenced in the $\mathrm{T}^{*}$-type one $\left(\mathrm{Pr}_{2-x} \mathrm{Sr}_{x} \mathrm{CuO}_{4+\delta}\right)$. In the T-type, the rare-earth has a quite large available space, occupying a 9-fold coordinated oxygen site, and as expected only $\mathrm{Pr}^{3+}$ is observed. In the T'-type structure, the corresponding coordinence is 8 , and the site should be also occupied by smaller ions such as $\operatorname{Pr}^{4+}(0.96 \AA$ instead of $1.126 \AA$ for $\mathrm{Pr}^{4+}$ and $\mathrm{Pr}^{3+}$, respectively). However, $\mathrm{Pr}^{4+}$ was not observed in the $\mathrm{T}^{\prime}$ structure as it could be expected, probably because the average $\mathrm{Pr}-\mathrm{O}$ bond is too large. In the $\mathrm{T}^{*}$-type structure, the rareearth occupies two inequivalent sites ( 9 and 8-fold coordinated, respectively), which seems to be the only favourable configuration suitable for accomodating the mixed valence state of praseodymium: $\mathrm{Pr}^{4+}$ is observed only in the 8-fold coordinated site while $\mathrm{Pr}^{3+}$ occupies the larger 9-fold coordinated site. Finally, for $\mathrm{Pr}_{2} \mathrm{NiO}_{4+\delta}$ with the T-type structure, only $\mathrm{Pr}^{3+}$ is observed as well as for the cuprate $\mathrm{Pr}_{2} \mathrm{CuO}_{4-\delta}$.

\section{Determination of the nickel oxidation state in $\mathrm{Pr}_{2} \mathrm{NiO}_{4+\delta}$}

In Figure 3 are plotted the XANES spectra recorded at the Ni K-edge for $\mathrm{Pr}_{2} \mathrm{NiO}_{4+\delta}$, in air and at different temperatures. All of them are included between two reference spectra related to $\mathrm{Ni}^{2+}(\mathrm{NiO})$ and $\mathrm{Ni}^{3+}\left(\mathrm{LaNiO}_{3}\right)$, themselves recorded at room temperature. This result first indicates that the mean average oxidation state of nickel stands between $2+$ and $3+$ in $\mathrm{Pr}_{2} \mathrm{NiO}_{4+\delta}$, whatever the temperature.

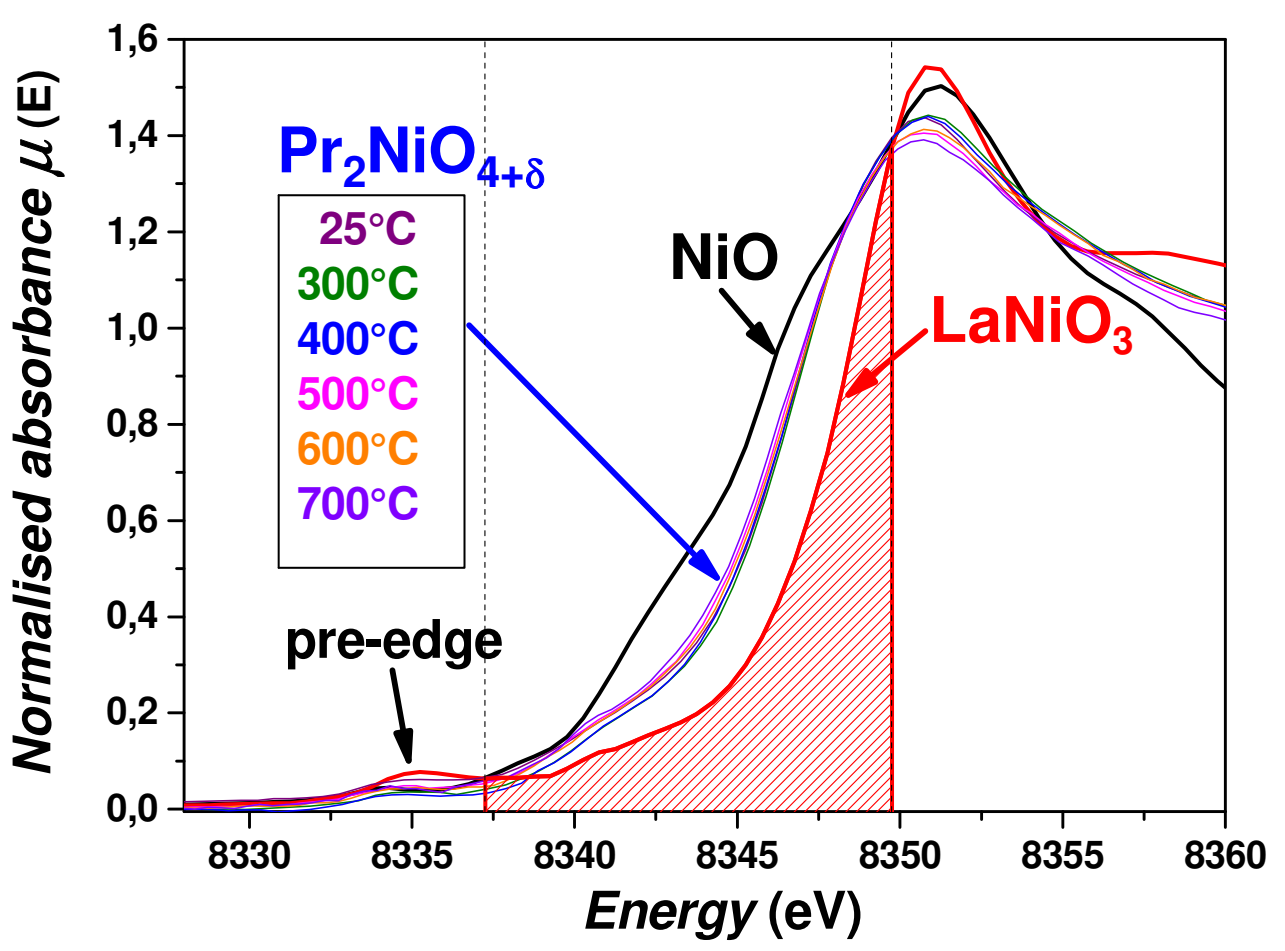


Figure 3. XANES data collected at the Ni K-edge for $\mathrm{Pr}_{2} \mathrm{NiO}_{4+\delta}$, in air as a function of temperature. Reference spectra of $\mathrm{NiO}$ and $\mathrm{LaNiO}_{3}$ (recorded at room temperature) are given. The integration area used for $\mathrm{LaNiO}_{3}$ (in red) is shown as an example. The pre-edge signals are indicated by an arrow.

As for $\mathrm{La}_{2} \mathrm{NiO}_{4+\delta}$ [29], a small pre-edge (arrow in Figure 3) is also visible, it is located around $8335 \mathrm{eV}$ for both $\mathrm{Pr}_{2} \mathrm{NiO}_{4+\delta}$ and $\mathrm{LaNiO}_{3}$, it is barely visible for $\mathrm{NiO}$. According to Mansour et al. [30], this pre-edge would result from the $1 \mathrm{~s} \rightarrow 3 \mathrm{~d}$ transition in close relation with the deformation of the $\mathrm{NiO}_{6}$ octahedra. For the reference materials, both the pre-edge intensity and its energy slightly increase with the mean oxidation state of nickel, this effect being probably correlated to the shift of Fermi level and Jahn-Teller effect of $\mathrm{Ni}^{3+}\left(3 \mathrm{~d}^{7}\right)$. The Ni Kedge location was determined using the intersection with the energy axis of the secondary derivative (with respect to the energy) of the absorbance curve. For the reference compounds, $\mathrm{NiO}\left(\mathrm{Ni}^{2+}\right)$ and $\mathrm{LaNiO}_{3}\left(\mathrm{Ni}^{3+}\right)$, the measured edge values (8345,83 and $8348,85 \mathrm{eV}$, respectively) are in good agreement with those reported in the literature $[29,31]$.

One can note that the edge energy position progressively decreases upon heating for $\mathrm{Pr}_{2} \mathrm{NiO}_{4+\delta}$, suggesting a decrease of the average nickel oxidation state, as expected. Using XANES measurements, Wooley et al. also determined the mean oxidation state of nickel in $\mathrm{La}_{2} \mathrm{NiO}_{4+\delta}$, at room temperature in air, as well as at $\mathrm{T}=$ $650^{\circ} \mathrm{C}$ under air and nitrogen [29]. As observed for $\mathrm{Pr}_{2} \mathrm{NiO}_{4+\delta}$, a shift of the nickel oxidation state towards lower values was also observed when heating the material in air as well as in low oxygen partial pressure. Moreover, the thermal evolution of the nickel $\mathrm{K}$-edge in $\mathrm{Pr}_{2} \mathrm{NiO}_{4+\delta}$ is in good agreement with that previously determined for $\mathrm{La}_{2} \mathrm{NiO}_{4+\delta}$ by Park et al. [32]. These authors also observed a slight shift of this edge towards higher values when the $\delta$ value increases, i.e. when the mean nickel oxidation state increases.

Numerical assessments were performed by evaluating the position of the maximum of the first derivative of the XANES curve (edge shift) or considering the area under the curves (integral). The second method has the benefit to be less sensitive to the energy sampling and it is particularly sensitive to the presence of isosbestic or pseudo-isosbestic points. In a second step, the first way to evaluate the average oxidation state consists in interpolating the previous values obtained at a given temperature to the straight line passing from the data recorded on model compounds $\left(\mathrm{Ni}^{2+}(\mathrm{NiO})\right.$ and $\left.\mathrm{Ni}^{3+}\left(\mathrm{LaNiO}_{3}\right)\right)$. This method called linear interpolation is widely used, but the results neglect the correlation between local structure and edge shift. In order to reduce this effect, we preferred to use an additional model compound, $\operatorname{Pr}_{2} \mathrm{NiO}_{4+\delta}$ whose composition at room temperature, i.e. the $\mathrm{Ni}$ oxidation state, is known from iodometric titration and TGA measurements under reducing condition $(+2.40)$ [22]. In this case, the average oxidation state is evaluated by interpolation from the parabola passing through the values obtained for these three standards. It is named quadratic interpolation.

The results obtained from edge position and the integral methods, using the quadratic interpolation in both cases are summarized in Table 1 and plotted in Figure 4 (left axis). One can see that the average oxidation state values obtained by edge shift quadratic interpolation as well as quadratic interpolation of the integrals are quite similar. One should note also that linear interpolations (results not reported) overestimate the values, probably due to the relatively strong variation of local structure of $\mathrm{NiO}$ with respect to $\mathrm{LaNiO}_{3}$ and $\mathrm{Pr}_{2} \mathrm{NiO}_{4+\delta}$, which confirms the choice of our calculation method.

Table 1. Thermal evolution, in air, of the Nickel K-edge positions according to the zero-crossing of the second derivative and corresponding spectra integrations, from XANES data recorded vs. $T$ for $\operatorname{Pr}_{2} \mathrm{NiO}_{4+\delta}$. The mean nickel oxidation states were determined according to quadratic interpolations, in both cases.

The corresponding data are given at $25^{\circ} \mathrm{C}$ for $\mathrm{NiO}$ and $\mathrm{LaNiO}_{3}$. 


\begin{tabular}{|c|c|c|c|c|}
\hline & $\begin{array}{l}\text { Edge } \\
\text { position } \\
\text { method }\end{array}$ & $\begin{array}{c}\text { mean } \mathrm{Ni} \\
\text { oxidation } \\
\text { state }\end{array}$ & $\frac{\text { Integral }}{\text { method }}$ & $\begin{array}{c}\text { mean } \mathrm{Ni} \\
\text { oxidation } \\
\text { state }\end{array}$ \\
\hline $\mathrm{NiO}\left(25^{\circ}\right)$ & $\overline{8345.72}$ & 2 & 3.542 & 2 \\
\hline $\mathrm{LaNiO}_{3}\left(25^{\circ}\right)$ & 8348.66 & 3 & 6.604 & 3 \\
\hline $25^{\circ}$ & 8346.84 & 2.40 & 5.154 & 2.40 \\
\hline $300^{\circ}$ & 8346.88 & 2.41 & 5.115 & 2.41 \\
\hline $400^{\circ}$ & 8346.82 & 2.39 & 5.231 & 2.37 \\
\hline $500^{\circ}$ & 8346.79 & 2.38 & 5.228 & 2.38 \\
\hline $600^{\circ}$ & 8346.73 & 2.36 & 5.262 & 2.37 \\
\hline $700^{\circ}$ & 8346.61 & 2.32 & 5.328 & 2.34 \\
\hline $800^{\circ}$ & 8346.44 & 2.26 & 5.662 & 2.24 \\
\hline
\end{tabular}

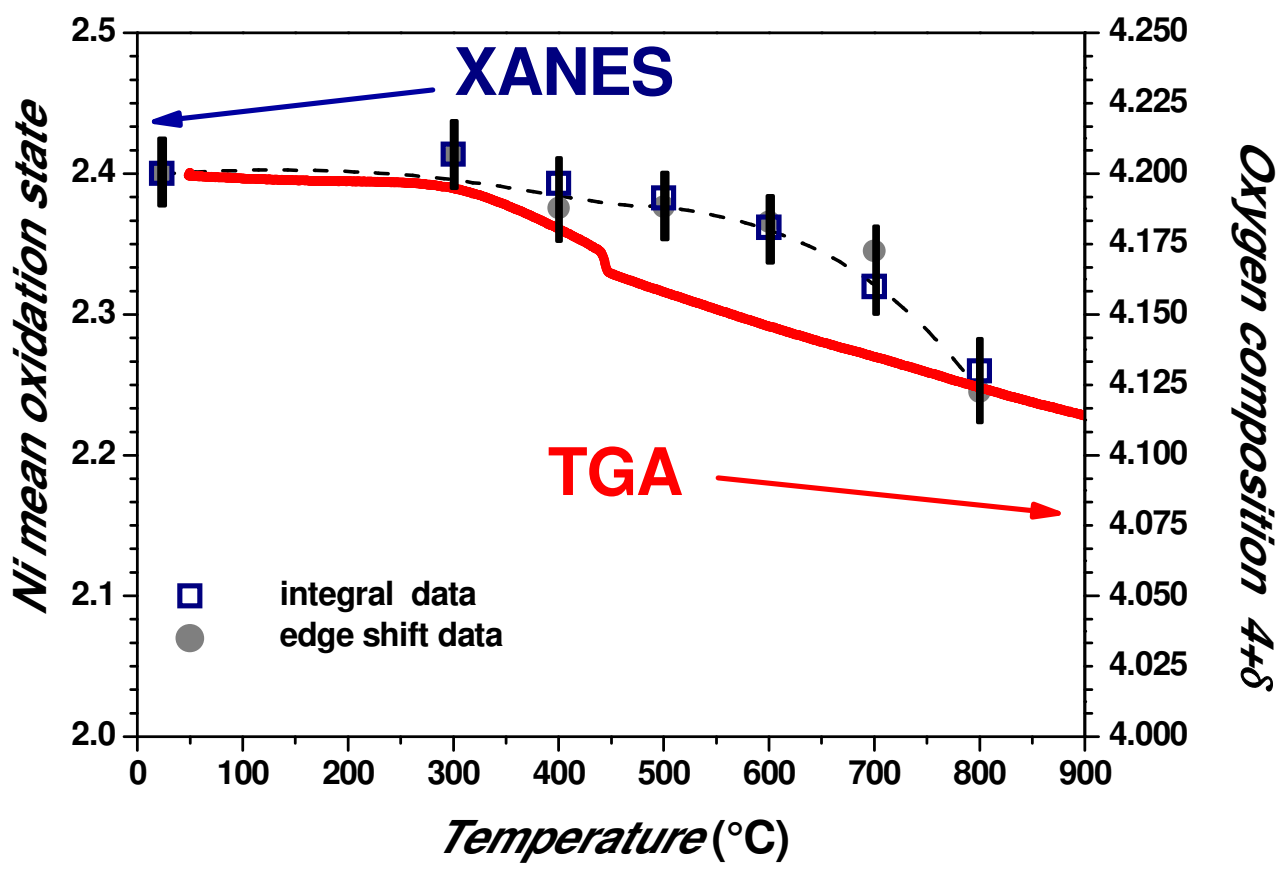

Figure 4. Thermal variation of: i) the Ni mean oxidation state as determined from XANES using quadratic interpolations of the data (cf. Table 1, scatter points, left axis). Blue dashed curve is a guide for the eye.

ii) the oxygen over-stoichiometry composition $4+\delta$ for $\mathrm{Pr}_{2} \mathrm{NiO}_{4+\delta}$, under air, as determined by TGA (right axis) [22].

Assuming the absence of $\mathrm{Pr}^{4+}$ cations, as shown above, and according to the modeling reported by Minervini et al. [33], we used the following charge compensation equilibrium for calculating the oxidation state of $\mathrm{Ni}$ : 


$$
\mathrm{O}^{2-}+2 \mathrm{Ni}^{3+} \leftrightarrow 1 / 2 \mathrm{O}_{2}+2 \mathrm{Ni}^{2+}(1)
$$

The experimental TGA data recorded in air [22] are plotted in Fig. 4 (-right axis, red curve). The corresponding mean nickel oxidation state of nickel, deduced from equilibrium (1), is reported on the left axis of Fig. 4.

Both set of data (XANES and TGA), which have been independently determined, can be compared. The mean oxidation state slightly decreases when the temperature increases for $T>\sim 400^{\circ} \mathrm{C}$ (Fig. 5, left axis). However the two curves (one relating to XANES data, the other relating to TGA data) exhibit a difference in shape; they only agree at low temperatures $\left(T \leq 300^{\circ} \mathrm{C}\right)$ with a good agreement only at RT and at $800{ }^{\circ} \mathrm{C}$. However such a difference should be expected due the different kinetics of the two experiments. Indeed, for both techniques a similar heating rate has been used but in the in-situ XANES the $\mathrm{Pr}_{2} \mathrm{NiO}_{4+\delta}$ powder was mixed with BN and compressed in self-supporting pellets, consequently at low temperatures the transformation kinetics was not only limited by oxygen conductivity but also by the gas diffusion in the pellets, while at high temperature this gas diffusion limitation becomes negligible. Finally, even if partly overestimating the absolute mean oxidation state of nickel, the XANES data recorded at the Ni-K edge evidence its progressive decrease upon heating, in rather good agreement with the TGA evolution. A significant increase of the nickel mean oxidation state and the corresponding oxygen composition $4+\delta$ is observed at the Low Temperature Orthorhombic (LTO) $\rightarrow$ High Temperature Tetragonal (HTT) phase transition (T $\approx 400$ $\left.{ }^{\circ} \mathrm{C}\right)$ (Fig. 4).

\section{Conclusion}

The aim of this study was to determine the oxidation states of praseodymium and nickel cations in $\operatorname{Pr}_{2} \mathrm{NiO}_{4+\delta}$, between $\mathrm{T}=25$ and $700^{\circ} \mathrm{C}$, under air. The analyses of the XANES spectra, recorded at the $\mathrm{L}_{\text {III }}$ edge of praseodymium, lead to conclude that this cation has only the oxidation state $3+$, as previously assumed by Zhang et al. [28] regarding $\mathrm{Pr}_{4} \mathrm{Ni}_{3} \mathrm{O}_{10 \pm \delta}$ material which belongs to the same RP series. From our viewpoint, $\mathrm{Pr}^{3+}$ cation is well accommodated in the nine-fold coordinated large rare-earth site of the T-type structure of this compound. Conversely, the $\mathrm{Pr}^{4+}$ cation of smaller size does not fit this site from a steric point of view.

The measurements performed at the nickel K-edge evidenced a progressive and slight decrease of the mean oxidation state of nickel at increasing temperature. Then, the electronic charge compensation mechanism linked with the decrease of the oxygen over-stoichiometry only involves the partial reduction of $\mathrm{Ni}^{3+}$ and leads to avoid, as could be assumed, the possible location of electronic holes on oxygen.

\section{Acknowledgments}

The authors gratefully express their thanks to the French Research National Agency (ANR) through «H2 and Fuel Cells program» (project FIDELHYO nANR-09-HPAC-005) for supporting this work. We acknowledge the European Synchrotron Radiation Facility for making available beam-time (beam-line BM23). 


\section{References}

[1] Y. Li, J.A. Kilner and M.F. Carolan, Solid State lonics 176, 937-943 (2005).

[2] D. Marinha, J. Hayd, L. Dessemond, E. Ivers-Tiffée and E. Djurado, J. Power Sources 196 (2011) 5084 5090 .

[3] S.J. Skinner and J.A. Kilner, Solid State lonics 135, 709 (2000).

[4] C. Ferchaud, Y. Zhang, J.C. Grenier, M. Van Tuel, F. Van Berkel and J.M. Bassat, J. Power Sources 196 (2011) 1872 - 1879.

[5] V. Vibhu, A. Rougier, C. Nicollet, A. Flura, J.C. Grenier and J.M. Bassat, Solid State lonics 278, 189 (2015).

[6] C. Nicollet, A. Flura, V. Vibhu, S. Fourcade, A. Rougier, J.M. Bassat and J.C Grenier, J. Solid State Electrochemistry 20 (7), 2071-2078 (2016).

[7] T. Ogier, J.M. Bassat, F. Mauvy, S. Fourcade, J.C. Grenier, K. Couturier, M. Petitjean and J. Mougin, Fuel Cells 13 (4), 536 (2013); T. Ogier, F. Mauvy, J.M. Bassat, J. Laurencin, J. Mougin and J.C. Grenier, Int. J. of Hydrogen Energy 40, 15885 (2015).

[8] M. Greenblatt, Current Opinion in Solid State and Materials Science, 2, 174, 1997.

[9] J.D. Jorgensen, B. Dabrowski, S. Pei, D.R. Richards and D.G. Hinks, Phys. Rev. B 40, 2187, 1989.

[10] D. Shannon, Acta Crystallographica A32, 751, 1976.

[11] M. Yashima, E. Enoki, T. Wakita, A.R. Ali, Y. Matsushita, F. Izumi and T. Ishihara, J. Am. Ceram. Soc. 130, 2762 (2008).

[12] J.M. Bassat, M. Burriel, O. Wahyudi, R. Castaing, M. Cerreti, P. Veber, I. Weill, A. Villesuzanne, J.C. Grenier, W. Paulus and J. A. Kilner, J. Phys. Chem. C. 117 (50), 26466-26472 (2013).

[13] J.M. Bassat, P. Odier and J.P. Loup, J. Solid State Chem. 110, 124 (1994); A. Flura, S. Dru, C. Nicollet, V. Vibhu, S. Fourcade, E. Lebraud, A. Rougier, J.M. Bassat and J.C. Grenier, J. Solid State Chem. 228, 189 (2015).

[14] C. Sieglaff and L. Eyring, J. American Chemical Society 79, 3024 (1957).

[15] B.G. Hyde and D. Bevan, Philosophical Transactions of the Royal Society of London, Series A, 259, 583 (1966).

[16] J. Abel, M. Lamirand-Majimel, J. Majimel, V. Bellière-Baca, V. Harlé, G. André, C. Prestipino, S. Figueroa, E. Durand and A. Demourgues, Dalton Trans. 2014, 43, 15183.

[17] Y. Ji, J.A. Kilner and M.F. Carolan, Solid State Ionics 2005, 176, 937.

[18] B.C.H. Steele and J-M. Bae, Solid State lonics 1998, 106, 255.

[19] A. Berenov, A. Atkinson, J.A. Kilner, E. Buche rand W. Sitte, Solid State Ionics 2010, 181, 819.

[20] M. Burriel, H. Tellez, R.J. Chater, R. Castaing, P. Veber, M. Zaghrioui, T. Ishihara, J.A. Kilner and J.M. Bassat, J. Phys. Chem. C. 2016, 120, 17927.

[21] T. Ogier, F. Chauveau, J.M. Bassat, F. Mauvy, J. C. Grenier, J. Mougin, M. Petitjean, ECS Transactions 2011, 35, 1817-1822. 
[22] Boehm, E.; Bassat, J. M.; Dordor, P.; Mauvy, F.; Grenier, J. C.; Stevens, P. Solid State Ionics 2005, 176, 2717-2725.

[23] C. Prestipino et al., "Quick-EXAFS Implementation on the General Purpose EXAFS Beamline at ESRF", Journal of Synchrotron Radiation 2011, 18, 176-182.

[24] J.F. Herbst and J.W. Wilkins, Phys Rev B 26 (1982) 1689.

[25] H. Dexpert, R.C. Karnatak, J.M. Esteva, J.P. Connerade, M. Gasnier, P. Caro and L. Albert, Phys.Rev.B 36, 1750 (1987).

[26] Z. Tan, S.M. Heald, S.W. Cheong, A. S. Cooper, J.I. Budnick, Phys.Rev.B 45, 2593 (1992).

[27] A. Kotani, K.O. Kvashnina, S.M. Butorin and P. Glatzel, Eur. Phys. J. B (2012) 85: 257.

[28] Z. Zhang and M. Greenblatt, J.Solid State Chem. 117, 236 (1995).

[29] R.J. Wooley, B.N. Illy, M.P. Ryan and S.J. Skinner, J. Mater. Chem. 21, 18592 (2011).

[30] A.N. Mansour, C.A. Melendres, M. Pankuch and R.A. Brizzolara, J. of the Electrochem Soc. 141, L69 (1994).

[31] W.E. O'Grady, K.I. Pandya, K.E. Swider and D.A. Corrigan, J. of the Electrochem Soc. 143, 1613 (1996).

[32] J.C. Park, D.K. Kim and J.H. Choy, J, Phys. IV France 7, C2-1217, 1997.

[33] L. Minervini, R.W. Grimes, J.A. Kilner and K.E. Sickafus, J. Mater. Chem. 10, 2349 (2000). 


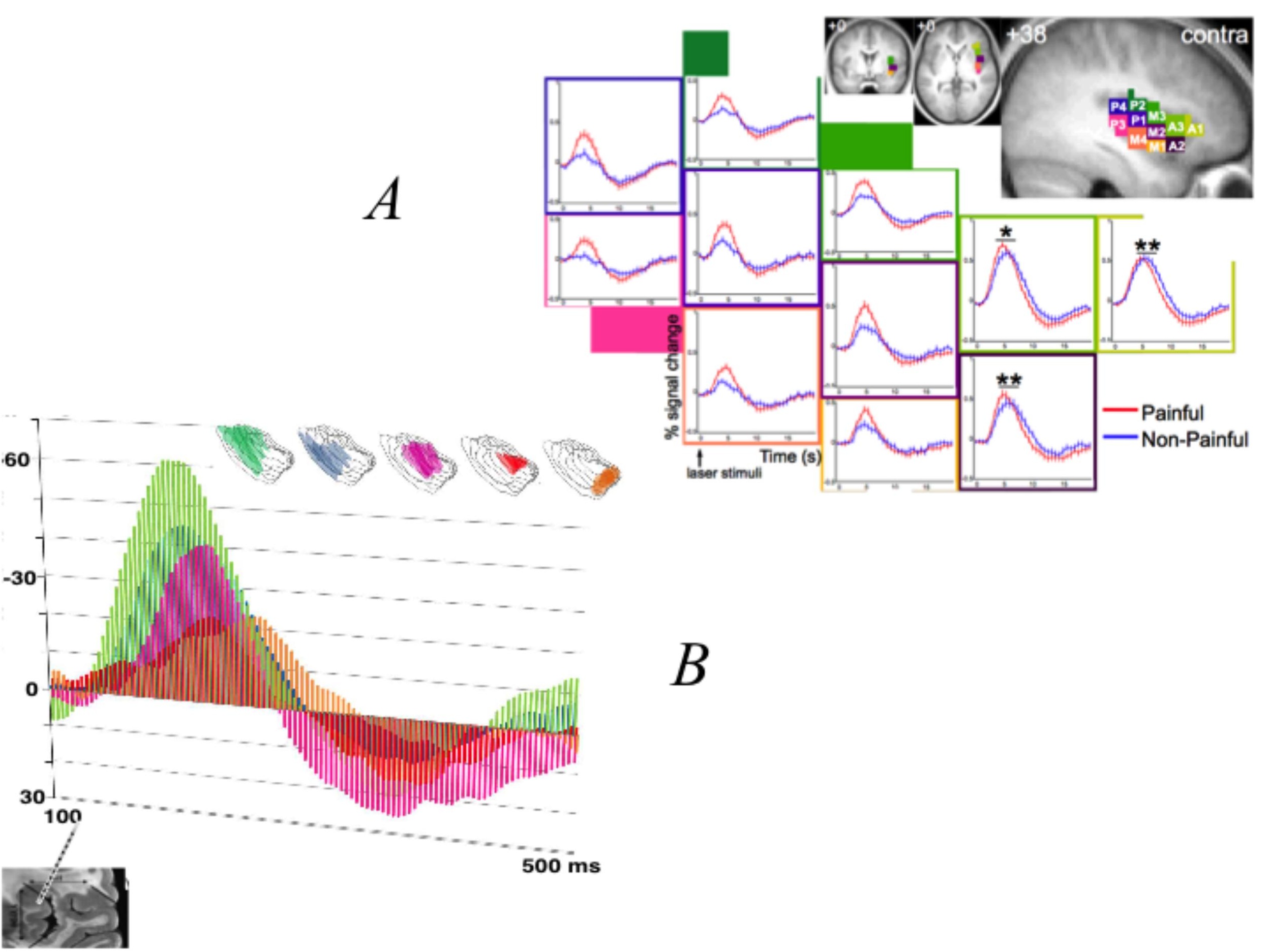

